\title{
An Experimental Study on Boron Carbide Reinforced Open Cell Aluminum Foams Produced via Infiltration Technique
}

\author{
Talha Sunar \\ Faculty of Technology \\ Department of Manufacturing Engineering \\ Karabuk University \\ Karabuk, Turkey \\ talhasunar@karabuk.edu.tr
}

\author{
Melik Cetin \\ Faculty of Technology \\ Department of Manufacturing Engineering \\ Karabuk University \\ Karabuk, Turkey \\ mcetin@karabuk.edu.tr
}

\begin{abstract}
Light structures and parts are very effective for new engineering applications. Their considerably low densities, high energy absorption capabilities, and desirable mechanical properties make them useful for particularly automotive, defense and aerospace industries. Besides these positive properties, it is known that the production and processing of cellular materials is very tough and worth the effort. Recently, with advances in new technologies like 3D printing or selective laser melting, now different types of cellular materials can be produced. But manufacturing of metallic foams via casting especially replication or infiltration method is fairly an economic method when compared with other methods. In this study, vacuum-gas infiltration set-up was used to produce $B 4 C$ reinforced aluminum foams. The mentioned method involves the addition of space holder materials and a dissolution technique to remove them after solidification of the metal. As space holder materials $\mathrm{NaCl}$ particles were selected and mixed with $\mathrm{B} 4 \mathrm{C}$ powders to produce $\mathrm{B} 4 \mathrm{C}$ reinforced $\mathrm{A360}$ aluminum foam. By changing the weight ratio of $\mathrm{B} 4 \mathrm{C}$ particles, the alteration of properties like porosity, compression strength, and energy absorption capacity was investigated. Additionally, computer tomography views were obtained to see and interpret the microstructures of the foams. Compression tests were carried out to evaluate the mechanical behavior of the foams under static loading. The porosities of samples obtained as between $65-75 \%$. The compressive strength increased with rising relative density.
\end{abstract}

Keywords-cellular materials; aluminum foam; space holders; replication

\section{INTRODUCTION}

Cellular materials and foams have attractive mechanical and physical properties like low density, high stiffness and thermal conductivity. These properties make them sufficient for advanced engineering applications. Generally, foam kind materials are characterized by their cell structures. There are two types of metal foam materials: open cell and closed cell metal foams. Open and closed cell metal foams have various definitions, but basically if the cells connect through open faces, so the gas phase is infinite, the foam can be defined as open celled. Otherwise, when the cell faces are closed and connected to their neighbors they can be defined as closed cells. The cell structure depends on the production method [1]. There are numerous manufacturing methods to produce metal foams $[1,2]$. The main difference between the production methods is the physical state of the main material which is processed. Porous metals can be formed from the initial state of liquid or solid metal [2]. The production method for this study is determined as replication or infiltration method which can be classified as foaming from liquid state. The casting of metals and alloys around the space holder material is a convenient and economical way to obtain metallic foams or cellular parts [3, 4]. The pore size and porosity can be controlled by modifying the process parameters like space holder particles (shape, size, material etc.), process pressure and method of infiltration [5, 6]. The infiltration process benefits from the melting point difference between the main metal and space holder materials. For example, in this study the melting temperature of A360 is $650^{\circ}-760^{\circ}$ [7] while the melting temperature of sodium chloride is $801^{\circ}$ [8]. To infiltrate aluminum into the sodium chloride space holder particles is required to melt aluminum at a temperature below the melting point of $\mathrm{NaCl}$ and apply pressure. The first study producing aluminum sponge from $\mathrm{NaCl}$ particles was carried out in 1961 [9]. Authors replicated molten aluminum into the sintered $\mathrm{NaCl}$ preform. The porosity and compression strength values of aluminum sponges were reported as $60 \%-63 \%$ and $20-30 \mathrm{MPa}$ respectively. In another study the porosity range for aluminum sponges was reported as $55 \%-67 \%$ [3]. Authors in [6], applied cold isostatically pressing to $400 \mu \mathrm{m} \mathrm{NaCl}$ particles and produced replicated foams which had $15-25 \%$ (75-85\% porosity) relative densities.

There are studies dealing with foaming of different main materials such as copper and magnesium using $\mathrm{NaCl}$ space holder particles. Copper foam was successfully produced with the use of $\mathrm{NaCl}$ particles via sintering-dissolution process and the resulting porosities were reported as $59.5 \%-71.3 \%$ [10]. In [11], a replication casting device was developed and $\mathrm{Mg}$ and $\mathrm{Mg}$ alloys with melting points lower than $950^{\circ}$ were manufactured. Open celled pure $\mathrm{Mg}$ and $\mathrm{Mg}-10 \mathrm{wt} \% \mathrm{Al}$ foams were produced with porosities of $70 \%$ and $67 \%$ respectively 
[11]. Other studies focused on the effects of cell shape and morphology to the mechanical behaviors of cellular metals and metallic foams. Open celled 6061 aluminum metal foam with different densities (5\%-10\%) characterized the compression. Density was reported as the primary variable controlling strength. The cell size was referred as it has insignificant influence [12]. Recent papers concentrated on cell geometry of lightweight structures. The mechanical properties of different honeycomb structures with the same relative density were investigated using finite element analysis. Cell geometry and arrangement highly affect the compression behavior and energy absorption capacity [13]. Selective laser melting was also used to produce lightweight similar-to foam steel structure with spherical porosity. Different cell arrangements applied, and samples had average porosities between $70.1 \%-72.5 \%$. As a result, shape geometry considerably affects compression properties [14]. Authors in $[15,16]$ dealt with the addition of ceramic particles into aluminum foams. $\mathrm{TiB}_{2}$ particles have been added to $\mathrm{Al}-\mathrm{TiH}_{2}$ compact to produce composite foam via powder metallurgy route. When compared with the $\mathrm{Al}$ foams, composite foams showed higher proof stress and absorbed more energy [15]. The mechanical properties of $\mathrm{B}_{4} \mathrm{C}$ reinforced $\mathrm{AlSi}_{7}$ foams produced powder metallurgy route were also investigated. It was reported that energy absorption values rise with increments in relative density and $\mathrm{B}_{4} \mathrm{C}$ content. Authors in [16] reported that $\mathrm{B}_{4} \mathrm{C}$ reinforced foams have approximately $28 \%$ higher bending strength compared to unreinforced foams. Metal foams can be reinforced with other particles to improve their physical and mechanical properties. Moreover, making this enhancement with an economic fabrication technique provides higher efficiency. Authors in [17] report that the higher production costs of metallic porous materials limits their application area. Thus, there is a good demand of cost-effective production methods that can correspond to the physical and mechanical properties for advanced industrial applications.

In infiltration method, commonly $\mathrm{NaCl}$ particles are used as space holder particles, but, to the best of our knowledge, there is not a study considering the effects of ceramic particle addition into the space holder media. Thus, in this study, A360 aluminum is foamed with the addition of different ratios of $\mathrm{B}_{4} \mathrm{C}$ (0\%-5\%) into the $\mathrm{NaCl}$ space holder media. Structure and microstructure were analyzed by $\mathrm{CT}$ and SEM\&XRD. The effects of $\mathrm{B}_{4} \mathrm{C}$ to the porosity, compression strength and energy absorption behaviors were investigated.

\section{EXPERIMENTAL STUDY}

For many lightweight applications aluminum or magnesium are preferred because of their physical, mechanical and chemical properties like corrosion resistivity. In this study A360 ( $\left.\mathrm{AlSi}_{10} \mathrm{Mg}\right)$ aluminum alloy was used as the main material. The metallic foam samples were produced using $\mathrm{NaCl}$ space holder particles with size range of $1.8 \mathrm{~mm}-2.8 \mathrm{~mm} . \mathrm{B}_{4} \mathrm{C}$ powders (325 mesh) were used for reinforcement particles for the projected metal foams. The contents of the A360 are given in Table I.

\section{A. Infiltration Process}

Infiltration process can be expressed as casting around space holder materials. Cellular structure can be obtained by removing the space holder materials. This process is also known as replication [18]. Infiltration of aluminum was carried out into an atmosphere controlled mold. The mold has been manufactured from 304 series steel in dimensions of $225 \mathrm{~mm}$ length, $101 \mathrm{~mm}$ external diameter and $5 \mathrm{~mm}$ wall thickness.

TABLE I. SPECTRAL ANALYSIS RESULTS AND COMMERCIAL DATA OF A360 CAST ALLOY

\begin{tabular}{|c|c|c|c|c|c|c|c|c|}
\hline Elements & $\mathrm{Si}$ & $\mathrm{Fe}$ & $\mathrm{Cu}$ & $\mathrm{Mn}$ & $\mathrm{Mg}$ & $\mathrm{Zn}$ & $\mathrm{Ni}$ & $\mathrm{Ti}$ \\
\hline Commercial data & $9-10$ & 0.5 & 0.1 & 0.4 & 0.3 & 0.1 & 0.1 & 0.1 \\
\hline Spectral analysis & 9.86 & 0.42 & 0.08 & 0.41 & 0.38 & 0.09 & 0.1 & 0.15 \\
\hline
\end{tabular}

To obtain standard main test material, pre-casting process was carried out and aluminum cylinder blocks $90 \mathrm{~mm}$ in diameter and $50 \mathrm{~mm}$ in length, were produced. A constant volume of space holder materials and aluminum block were placed into the mold. $\mathrm{B}_{4} \mathrm{C}$ particles were added and mixed with the $\mathrm{NaCl}$ space holder particles. To compare the effects of ceramic addition on strength, three samples were produced without ceramic addition. The mold was placed in a furnace set to $720^{\circ}$. Before infiltration, vacuum process was applied to the mold in order to avoid oxidation by removing the air from the mold. The temperature and vacuum pressure were kept constant during melting. The next step after melting was to initiate infiltration with the help of pressure. Argon gas used to supply constant 2 bar pressure to press aluminum [19]. Cooling was performed at room temperature. Several conventional operations such as cutting and turning were carried out to get uniform shape before the dissolution process of space holder particles. With the aim of removing the space holder particles from the main material, dissolution process was performed inside 2 liter water tanks at temperature of $90^{\circ}$ for 1 hour. A magnetic stirrer hot plate was utilized for better dissolution performance. Beside that, to improve solubility, after half an hour the water was refreshed. With this technique, $\mathrm{B}_{4} \mathrm{C}$ reinforced foams were produced with 14 different weight ratios of $\mathrm{B}_{4} \mathrm{C}: 0.25 \%, 0.5 \%, 0.75 \%, 1 \%, 1.25 \%, 1.5 \%, 1.75 \%, 2 \%$, $2.5 \%, 3 \%, 3.5 \%, 4 \%, 4.5 \%$ and $5 \%$. The samples were named with respect to their ceramic content, e.g. F1.75 represents foam sample which is manufactured with $1.75 \% \mathrm{~B}_{4} \mathrm{C}$ content. Figure 1 shows a metal block and the resulting foam sample.

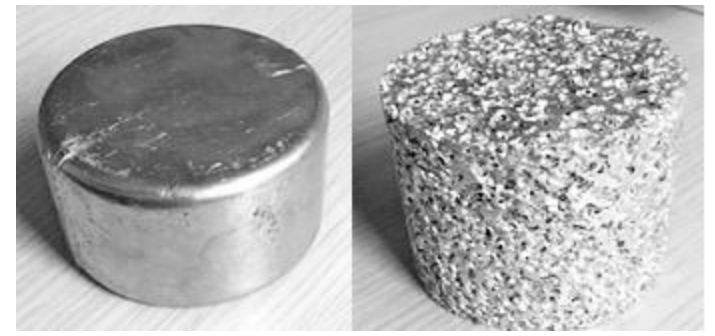

Fig. 1. Aluminum block and resulting foam sample.

\section{B. Compression Tests}

To investigate the effects of $\mathrm{B}_{4} \mathrm{C}$ reinforcement to the compression behavior of the foam, compression tests were carried out with the following test parameters: Test specimens had dimensions of $80 \mathrm{~mm}$ length and $50 \mathrm{~mm}$ diameter. The crosshead speed was determined as $0.005 \mathrm{~s}^{-1}$. All parameters 
were selected as compatible with the standard of ISO 13314 compression test for porous and cellular metals [20]. Zwick/Roell $600 \mathrm{kN}$ mechanical test machine has been used for compression tests. Each test was repeated three times and the mean values were extracted to provide experimental accuracy. The standard ISO 13314 provides the definition and application of basic terms for mechanical test results for cellular materials such as first maximum stress, plateau stress $\sigma_{p l}$, plateau end $\sigma_{p l e}$ and absorbed energy $\mathrm{W}$. Plateau stress values were calculated as the average of the stress data between $20 \%$ and $30 \%$ compressive strain range on the stress-strain curve. Plateau end estimated the stress value as 1.3 times greater of the plateau stress. The energy absorptions of the samples were computed as the area under stress-strain curve up to the plastic strain of $50 \%$. Both data analysis and calculations were performed in accordance with the standard.

\section{Porosity and Microstructure Investigations}

The foam samples formed cubical shapes and sandpapered to perform basic metallography examination. Micro-structural investigation of the foam surfaces was performed using Carl Zeiss Ultra Plus scanning electron microscope (SEM) supplied with an energy dispersive spectrometer (EDS, Bruker X Flash $6 / 10)$. Cell walls and truss sections were viewed and mapping images were taken to observe element distributions. Component identification was carried out using Rigaku Ultima IV XRD test machine with $\mathrm{Cu} K a$ radiation $(\lambda: 1.54 \mathrm{~A})$ and scanning speed of $3^{0} \mathrm{~min}$. Diffraction patterns were generated with 2 theta (Bragg angle) between $10^{\circ}$ and $90^{\circ}$. The density of foam samples derived from their weights and volumes [10]. Equation (1) gives the porosity:

$$
P=\left(1-\rho_{p} / \rho_{b}\right) \times 100
$$

where $\mathrm{P}$ is the porosity of the foam, $\rho_{p}$ is the density of porous or foam material $\rho_{b}$ is density of bulk material. The fraction of $\rho_{p} / \rho_{b}$ is defined as the relative density of the foam [21].

\section{RESULTS AND DISCUSSION}

\section{A. Structure and Porosity of the Samples}

Al foam resulting samples were defined as open celled when computer tomography images were examined. The sample foams did not have uniformly shaped space holder particles. Thus, it was not possible to refer constant average cell size. The space holder material dimensions varied between $1.8 \mathrm{~mm}-2.8 \mathrm{~mm}$. Aluminum foams were scanned with the 3D computer tomography device and $3 \mathrm{D}$ geometric data were obtained. Figure 2 shows the alloy (without $\mathrm{B}_{4} \mathrm{C}$ ) foam sample's 3D and section views. Results show that the samples had homogenous pore distributions. The produced metal foam samples had different porosities, approximately in the range of $65 \%-75 \%$ agreeing with similar studies. Several papers reported porosity range between $55 \%-67 \%$ (81\% when $\mathrm{NaCl}$ was pre-sintered). Maximum porosities obtained were limited and below $80 \%$ [3, 22]. Figure 10 shows the mean porosity values for different samples. When the porosity results were analyzed, there was seen a complex effect of $\mathrm{B}_{4} \mathrm{C}$ on porosity. Less porous structure was obtained when the $\mathrm{B}_{4} \mathrm{C}$ content was in the range of $0.25 \%-2 \%$. The lowest porosity value was $63 \%$ and was observed in the sample F0.5. SEM and EDX investigations were done on the truss faces and cell walls.

Figure 3 illustrates the combination area of cell wall and the truss section. EDX/EDS analysis showed that boron and carbon were highly placed at the cell wall for all the samples. These phenomena can be understood because $\mathrm{B}_{4} \mathrm{C}$ particles were mixed with $\mathrm{NaCl}$ particles so it's clear that the cell wall would have more ceramic content. The resulting images of the samples which were mixed with higher ratio of $\mathrm{B}_{4} \mathrm{C}$ showed more obvious boron and carbon content according to Figures 47. The point analysis showed the same trend. Figure 8 shows the results of point analysis fom different samples. XRD diffraction pattern graph is shown in Figure 9. XRD analysis results showed that there are $\mathrm{B}_{4} \mathrm{C}\left(\sim 32^{0}\right.$ and $\left.\sim 38^{\circ}\right)$ and $\mathrm{Al} 3 \mathrm{BC}$ $\left(\sim 44^{0}\right)$ compounds.

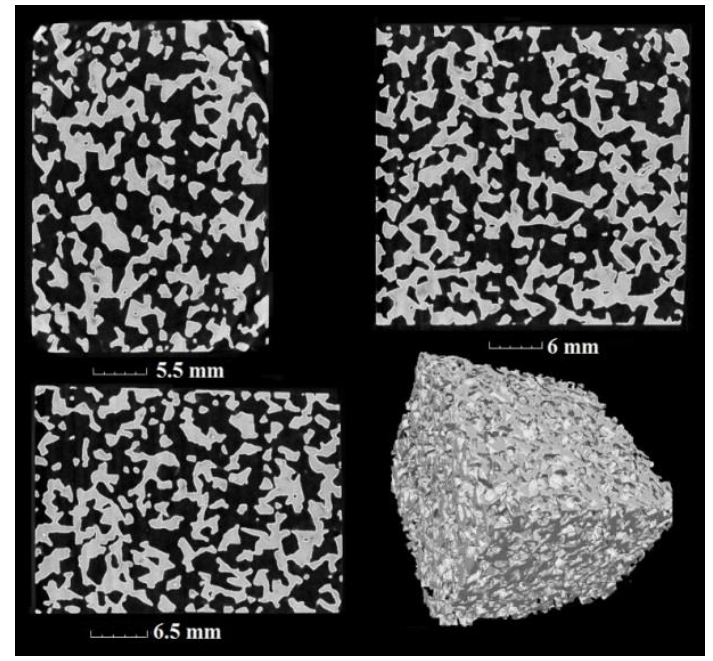

Fig. 2. Computer tomography images of A360 foam sample.

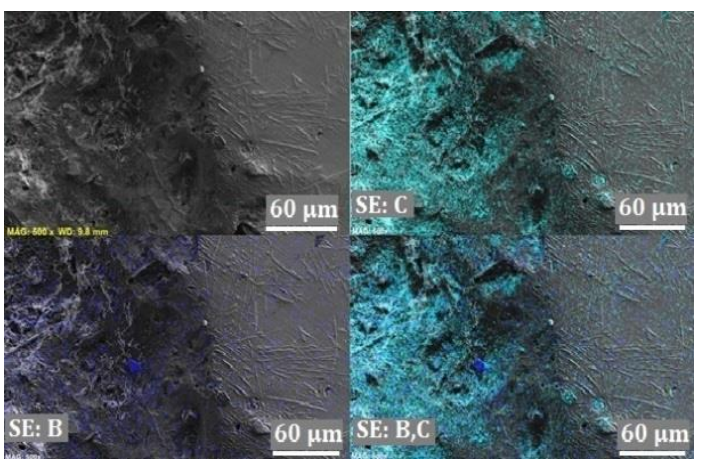

Fig. 3. EDS mapping images for the region of combination cell walls and truss faces of F.175 sample.

\section{B. Mechanical Behaviour of The Foams}

To investigate the effects of $\mathrm{B}_{4} \mathrm{C}$ reinforcement on the compression behavior of the foams, compression tests were carried out. The compressing test procedure and the test results are shown in Figure 10 and Table II. Mean data were extracted from the original 3 data series. The sample F0.5 which was reinforced with $0.5 \% \mathrm{~B}_{4} \mathrm{C}$ had better mechanical properties from the other series (see Figure 10). 


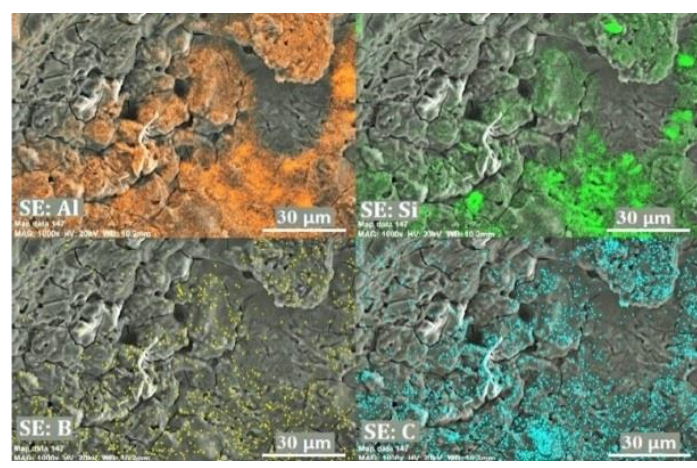

Fig. 4. EDS mapping images of cell wall of F0 sample.

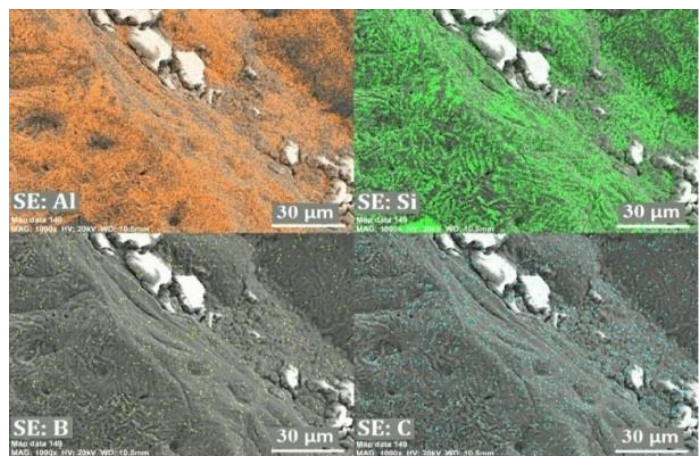

Fig. 5. EDS mapping images of cell wall of F0.5 sample.

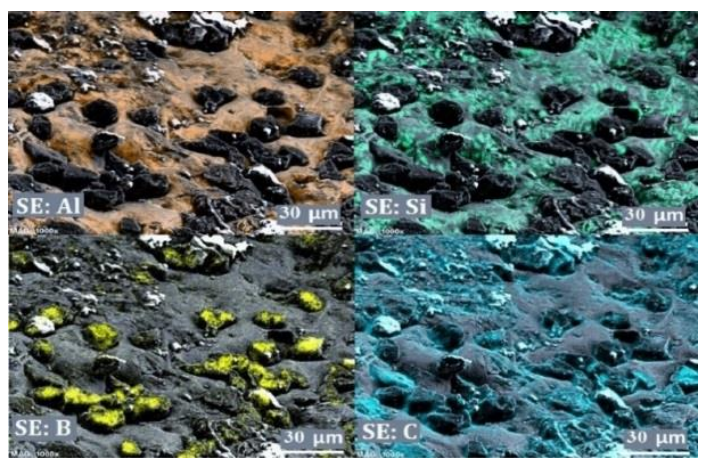

Fig. 6. EDS mapping images of cell wall of F1.75 sample.

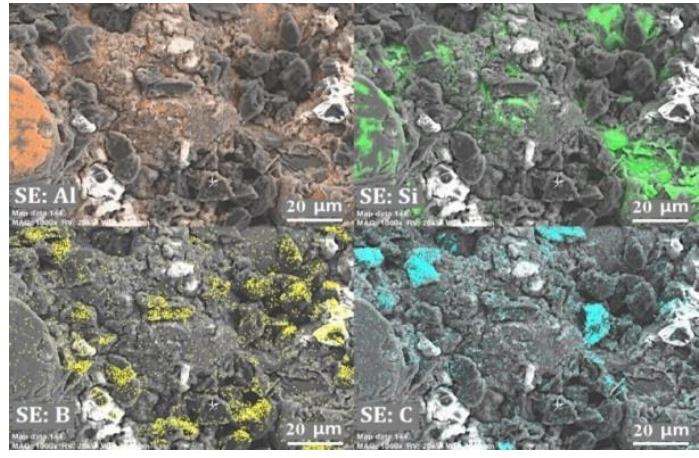

Fig. 7. EDS mapping images of cell wall of F5 sample.

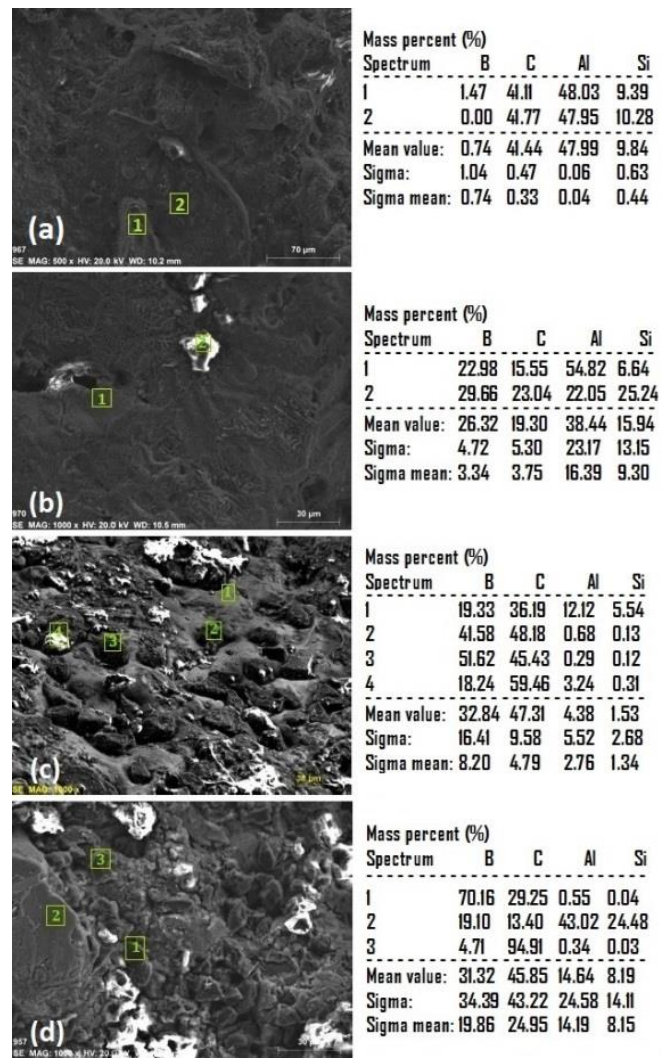

Fig. 8. EDS analysis of cell walls of the samples: (a) F0, (b) F0.5, (c) F1.75 and (d) F5.

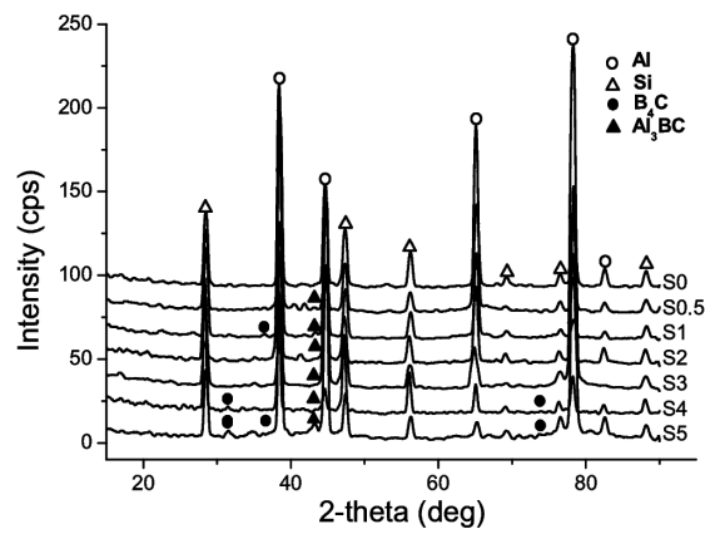

Fig. 9. XRD diffraction pattern graph of foam samples.

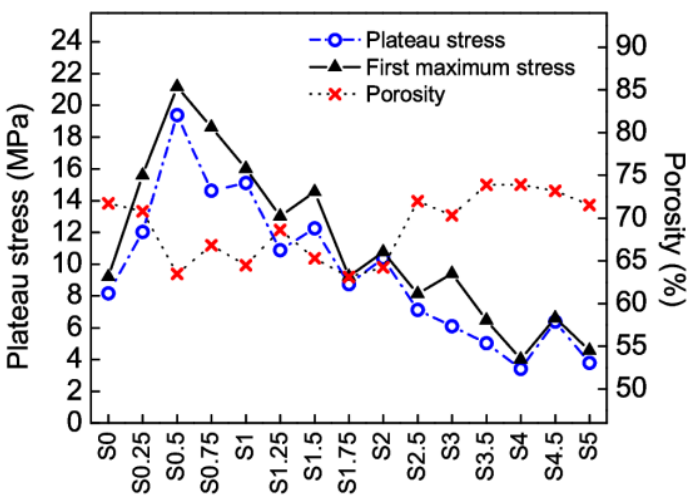

Fig. 10. Compression test results with the porosities of the foam samples. 
When compression test results were analyzed, F0.5 had 21.2MPa first maximum stress and $19.45 \mathrm{MPa}$ plateau stress. F0.75 showed the second highest results with values of 18.61 MPa first maximum stress and 15.15MPa plateau stress. The mechanical behavior of metallic foams differs, depending on several factors such as the properties of base metal, relative density, pore size and heterogeneity $[16,23]$. The compressive properties increase consistently with increasing relative density [6]. By raising the relative density compression the curve slides vertically because of greater strength [24]. In this study, porosity is an important parameter for mechanical properties. Except minimal increments, both first maximum stress and plateau stress values showed decreasing trend with the addition of $\mathrm{B}_{4} \mathrm{C}$ to the $\mathrm{NaCl}$ media. Higher $\mathrm{B}_{4} \mathrm{C}$ addition into the $\mathrm{NaCl}$ media caused less compressive strength.

TABLE II. COMPRESSIVE TEST RESULTS DATA OF FOAM SAMPLES

\begin{tabular}{|c|c|c|c|c|}
\hline Samples & $\begin{array}{c}\text { First max } \\
\text { strength [MPa] }\end{array}$ & $\begin{array}{c}\text { Plateau stress } \\
{[\mathbf{M P a}]}\end{array}$ & $\begin{array}{c}\text { Plateau end } \\
{[\mathbf{M P a}]}\end{array}$ & $\begin{array}{c}\text { Absorbed } \\
\text { energy }[\mathbf{k j} / \mathbf{m} 3]\end{array}$ \\
\hline F0 & 9.224 & $7.830 \pm 2.3$ & 10.179 & 3107 \\
\hline F0.25 & 15.664 & $12.195 \pm .8$ & 15.854 & 5938 \\
\hline F0.5 & 21.196 & $19.448 \pm 1.8$ & 25.283 & 7310 \\
\hline F0.75 & 18.614 & $15.155 \pm 4.9$ & 19.702 & 5017 \\
\hline F1 & 16.05 & $14.144 \pm 3.5$ & 18.387 & 3938 \\
\hline F1.25 & 13.028 & $11.105 \pm 1.1$ & 14.437 & 5129 \\
\hline F1.5 & 14.596 & $11.230 \pm 2.4$ & 14.598 & 2628 \\
\hline F1.75 & 9.23 & $8.486 \pm 2$ & 11.032 & 2815 \\
\hline F2 & 10.767 & $10.407 \pm 2.3$ & 13.530 & 3908 \\
\hline F2.5 & 8.133 & $6.229 \pm 2.2$ & 8.098 & 2176 \\
\hline F3.0 & 9.4 & $6.745 \pm 1.2$ & 8.768 & 2939 \\
\hline F3.5 & 6.511 & $6.4 \pm 1.7$ & 8.320 & 2525 \\
\hline F4.0 & 4.021 & $3.594 \pm 1.3$ & 4.672 & 1397 \\
\hline F4.5 & 7.022 & $6.362 \pm 0.9$ & 8.271 & 2422 \\
\hline F5 & 4.52 & $3.624 \pm 2.6$ & 4.711 & 1602 \\
\hline
\end{tabular}

\section{CONCLUSIONS}

An experimental study was conducted on the replication of $\mathrm{B}_{4} \mathrm{C}$ reinforced $\mathrm{A} 360$ aluminum foams. Fourteen different series of aluminum foam were manufactured successfully. The outcomes of this study are concluded as follows: Metal foams were open celled and the pores were distributed homogeneously. The pore shapes were not uniform because of the natural complex forms of space holder particles. Thus, cell sizes ranged between $1.8 \mathrm{~mm}$ and $2.8 \mathrm{~mm}$. The porosity of the acquired metal foams was between $65 \%-75 \%$. The effect of $\mathrm{B}_{4} \mathrm{C}$ on the porosity was not proportional. In the range of $0.25 \%-2 \% \mathrm{~B}_{4} \mathrm{C}$ content, the porosities of the foams were lower. On the other hand, A360 aluminum foam (without ceramic addition) and the foams produced with higher than $2 \% \mathrm{~B}_{4} \mathrm{C}$ reinforcement showed higher porosity values. $\mathrm{B}_{4} \mathrm{C}$ particles were distributed mostly at the cell walls. XRD analysis results showed that there were $\mathrm{B}_{4} \mathrm{C}$ and $\mathrm{Al}_{3} \mathrm{BC}$ compounds. The compressive properties of metallic foams increase consistently with increasing relative density. The sample F0.5 had the lowest porosity and showed the best mechanical properties. First maximum stress and plateau stress values decreased with the addition of $\mathrm{B}_{4} \mathrm{C}$.

\section{ACKNOWLEDGMENT}

Authors would like to thank Karabuk University Coordinatorship of Research Projects (BAP) and The Scientific and Technological Research Council of Turkey (TUBITAK) for their financial support for this study (Project numbers are KBUBAP-17-DR-051 and 215M233 respectively).

\section{REFERENCES}

[1] L. J. Gibson, M. F. Ashby, Cellular Solids, Pergamon Press Ltd., Cambridge, 1997

[2] J. Banhart, "Manufacture, characterization and application of cellular metals and metal foams", Progress in Materials Science, Vol. 46, No. 6, pp. 562-563, 2001

[3] J. Banhart, "Properties and Applications of Cast Aluminum Sponges", Advanced Engineering Materials, Vol. 2, No. 4, pp. 188-194, 2000

[4] R. Goodall, A. Mortensen, "Microcellular aluminum? Child's play!", Advanced Engineering Materials, Vol. 9, No. 11, pp. 951-954, 2007

[5] S. B. Pimiento, M. E. Hernandez-Rojas, M. E. Palomar-Pardave, "Processing and characterization of open-cell aluminum foams obtained through infiltration processes", Procedia Material Science, Vol. 9, pp. 54-61, 2015

[6] J. F. Despois, A. Marmottant, L. Salvo, A. Mortensen, "Influence of the infiltration pressure on the structure and properties of replicated aluminum foams", Materials Science and Engineering: A, Vol. 462, No. 1-2, pp. 68-75, 2007

[7] ASM Handbook, Properties and Selection: Nonferrous Alloys and Special-Purpose Materials, Vol. 2 pp. 889-896, ASM International, 1990

[8] W. M. Haynes, CRC Handbook of Chemistry and Physics, CRC Press LLC, pp. 89, 2013

[9] L. Polonsky, S. Lipson, H. Markus, "Lightweight Cellular Metals", Modern Castings, Vol. 39, pp. 57-71, 1961

[10] Q. Z. Wang, C. X. Cui, S. J. Liu, L. C. Zhao, "Open-celled porous $\mathrm{Cu}$ prepared by replication of $\mathrm{NaCl}$ space-holders", Materials Science and Engineering: A, Vol. 527, No. 4-5, pp. 1275-1278, 2010

[11] G. A. Lara-Rodriguez, I. A. Figueroa, M. A Suarez, O. Novelo-Peralta, I. Alfonso, R. Goodall, "A replication casting device for manufacturing open cell Mg foams", Journal of Materials Processing Technology, Vol. 243, pp. 16-22, 2017

[12] T. G. Nieh, K. Higashi, J. Wadsworth, "Effect of cell morphology on the compressive properties of open-cell aluminum foams", Materials Science and Engineering: A, Vol. 283, No. 1-2, pp. 105-110, 2000

[13] F. N. Habib, P. Iovenitti, S. H. Masood, M. Nikzad, "Cell geometry effect on in-plane energy absorption of periodic honeycomb structures", International Journal of Advanced Manufacturing Technology, Vol. 94, No. 5-8, pp. 2369-2380, 2018

[14] F. Caiazzo, S. L. Campanelli, F. Cardaropoli, N. Contuzzi, V. Sergi, A. D. Ludovico, "Manufacturing and characterization of similar to foam steel components processed through selective laser melting", International Journal of Advanced Manufacturing Technology, Vol. 92, Vol. 5-8, pp. 2121-2130, 2017

[15] A. R. Kennedy, S. Asavavisitchai, "Effects of $\mathrm{TiB}_{2}$ particle addition on the expansion, structure and mechanical properties of PM Al foams", Scripta Materialia, Vol. 50, No. 1, pp. 115-119, 2004

[16] A. Uzun, M. Turker, "The investigation of mechanical properties of B4C-reinforced AlSi7 foams", International Journal of Materials Research, Vol. 106, No. 9, pp. 970-977, 2015

[17] B. Zhao, A. K. Gain, W. Ding, L. Zhang, X. Li, Y. Fu, "A review on metallic porous materials: pore formation, mechanical properties, and their applications", The International Journal of Advanced Manufacturing Technology, Vol. 95, No. 5-8, pp. 2641-2659, 2018

[18] Y. Conde, J. F. Despois, R. Goodall, A. Marmottant, L. Salvo, C. San Marchi, A. Mortensen, "Replication processing of highly porous materials", Advanced Engineering Materials, Vol. 8, No. 9, pp. 795-803, 2006

[19] T. Sunar, M. Cetin, "Production of Open Cell Aluminum Foam by Vacuum Casting Method", 8th International Advanced Technologies Symposium, Elazig, Turkey, October 19-22, 2017 
[20] ISO, ISO 13314:2011, Mechanical Testing of Metals, Ductility Testing, Compression Test for Porous and Cellular Metals, International Organization for Standardization, 2011

[21] J. A. Liu, F. Gao, Y. Q. Rao, C. L. Wu, Y. Liu, "Compressive Properties of Aluminum Foams Produced by Replication Route using Spheroidal Calcium Chloride as Space Holder", Materials Transactions, Vol. 55, No. 12, pp. 1906-1908, 2014

[22] C. San Marchi, A. Mortensen, Handbook of Cellular Metals Production, Processing, Applications, pp. 44-56, Wiley-VCH, 2002

[23] U. Ramamurty, A. Paul, "Variability in mechanical properties of a metal foam", Acta Materialia, Vol. 52, No. 4, pp. 869-876, 2004

[24] Q. Fabrizio, A. Boschetto, L. Rovatti, L. Santo, "Replication casting of open-cell AlSi7Mg0.3 foams", Materials Letters, Vol. 65, No. 17-18, pp. 2558-2561, 2011 